\title{
Introduction: China and International Development: Challenges and Opportunities
}

\author{
Jing Gu, Xiaoyun Li, Gerald Bloom and Xiulan Zhang
}

\begin{abstract}
In parallel to its domestic economic boom, China has also been growing as an international actor and as a 'Rising Power' in global development. This introduction outlines the need for further understanding of China's own development experience, its increasing involvement in development activities in low- and middle-income countries, and its growing engagement in global governance structures. The articles highlighted contribute valuable expertise and insight from both Chinese and non-Chinese perspectives, to map the shifting landscape of China's engagement in global development, and contribute to mutual understanding between traditional donors and rising powers in development cooperation.
\end{abstract}

前言: 中国与世界发展: 机遇和挑战

谷靖, 李小云, 杰瑞・布鲁姆, 张秀兰

在过去三十多年间, 中国发展的成就与代价都很显著, 世界对 “崛起大国” 中国的 全球影响越来越关注。近年来中国在国际发展中的角色逐步提升, 中国与非洲的关 系尤其受到重视。我们如何解释和理解中国意义上的 “发展” ? 中国自己的发展路 径对主流发展理论有何启示? 在这一背景下, 这期特刊汇集了中外专家对中国高速 发展以及与其他中低收入国家的关系与互动的经验教训分析。 
This IDS Bulletin focuses on China's development strategy and how it is influencing the country's engagement in other low- and middle-income countries, as well as its collaboration with Organisation for Economic Co-operation and Development-Development Assistance Committee (OEGD-DAC) members in international development. Its aim is to contribute to dialogue between decision-makers, policy analysts and researchers in China, the UK and other countries, about strategies for supporting development. It is an output of the Rising Powers in International Development Programme at the Institute of Development Studies (IDS), a partnership between policy analysts in the UK and the rising powers.

The Rising Powers in International Development Programme examines how the growing influence of the rising powers is challenging the paradigm of international development and aid relations that emerged at the end of the colonial era. One important strand of its work is on mutual learning about the development experiences of the rising powers and their engagement in other low- and middle-income countries. The roles of the four editors reflect the way the programme generates this mutual learning. Jing Gu, of IDS, convenes the programme, and she has led its work on debates in the Chinese development community about the country's engagement in low- and middle-income countries. Xiaoyun Li, of China Agricultural University, is a member of the programme's Advisory Council. He is an international expert on China's engagement in African agriculture, and China's policy on international development. Gerald Bloom, of IDS, convenes a programme of Senior International Associates, which provides an opportunity for highly experienced policy actors and policy analysts from the rising powers to reflect on lessons from their country's development experience for other low- and middle-income countries. He has been working with researchers and policymakers from several of the BRICS countries (Brazil, Russia, India, China and South Africa) to create opportunities for mutual learning on strategies for health system development. Xiulan Zhang, of Beijing Normal University, is a Senior International Associate, who undertook a review of the evolution of China's rural health reform policy to identify lessons for other low- and middle-income countries. She is leading a number of efforts to apply lessons from China's experience to development thinking and practice.

There are several reasons for our decision to produce an issue of the IDS Bulletin which focuses on China. First is China's success in achieving economic development and poverty reduction. From the 1980s to the present day, the government has invested a great deal of money in its less developed provinces. This was, by far, the largest development programme of that period. There is little doubt that the understandings about development of Chinese government officials, heads of companies and researchers were strongly influenced by this experience. However, development experts from other countries have had little access to systematic studies of what worked and why in China's development efforts. This difference in level of knowledge constitutes an important barrier to building mutual understanding of how to support development in low- and middleincome countries. The initial idea for this special issue was a request that emerged during an annual meeting of the Development Studies Association of the UK for opportunities to learn more about the Chinese approach to development and the implications for the evolving practice of international development.

Second is the growing involvement of the Chinese government and Chinese private companies in low- and middle-income countries. This has happened rapidly and there is little systematic information on what is happening, the differences in approach from the existing development paradigms, and its effect on the international development architecture. This is creating challenges for Chinese actors, who need to learn very quickly how to operate effectively in new and changing contexts. It is also creating challenges for development actors in the host countries and for the traditional donors, who need to find ways to work with their Chinese counterparts.

Third is the growing engagement of the Chinese government in global organisations, global initiatives and global governance arrangements. This makes it increasingly important that the officials involved from China and from other countries (and the policy analysts who advise them) find ways to work together despite their different cultures, languages and historical legacies. 
One aim of this IDS Bulletin is to contribute to the construction of mutual understanding between the 'development communities' of China, the UK and other participants in global development. This is an important first step towards the creation of new understandings of development in the multi-polar world that is emerging. This understanding must reflect the many lessons learned from the recent development experiences of China and the other rising powers. These new understandings can then inform dialogue about appropriate rules of engagement and new ways of governing the global development effort.

The articles in this special issue were submitted in response to a call for papers circulated to development analysts in China and to those with a special interest in China's engagement in lowand middle-income countries. The editors reviewed the abstracts in terms of their relevance to the topic and their likely contribution to knowledge. We sought to ensure a balance between people with special expertise in China's development experience and those with experience of China's engagement in the development processes of other countries, and between authors primarily working in China and those working in other countries. The resulting collection illustrates the degree to which reality has been running ahead of our ability to analyse it. It provides a number of insights into different aspects of China's internal development experience, of the understandings of Chinese policy analysts and of the reality of Chinese engagement in several countries. It illustrates the different viewpoints that are emerging, depending on the perspective from which the authors have written. It also highlights the important contribution that research can make towards productive collaboration in addressing the major development challenges.

There are many different understandings of the implications of China's growing engagement in low- and middle-income countries. First, it is instructive to contrast 'Western' narratives with the Chinese one presented in the article by $\mathrm{Hu}$ et al. The authors look forward to a future in which China's rapid development is understood to have been a precursor to what they call 'the great convergence' in which inter-country inequalities decrease, although intra-country inequalities remain large. They foresee a twenty-first century in which China will play an important role in the construction of a 'world of great harmony'. This understanding of China's development experience and vision of future global influences will affect the day-to-day processes of Chinese engagement on the ground in low- and middleincome countries and in global discussions, and help build new and effective global development partnerships.

The existence of these competing and very different perspectives reflects the magnitude of the changes taking place and the lack of systematic knowledge on which to base these analyses. Several of the articles are aimed at bridging this knowledge gap. The article by Li $e t$ al. recounts China's long history of engagement with a number of developing countries. The authors argue that the form of this engagement has reflected China's own development path and, to a lesser extent, broad international development goals. They illustrate this with the case of Chinese agricultural aid to Africa.

Between the 1950s and 1970s, when China's development strategy gave priority to agriculture, its development assistance did the same. The assistance used approaches believed to have been effective in China. The type of assistance provided changed after the introduction of China's economic reforms in the late $1970 \mathrm{~s}$, with a more business-oriented model of aid. As China's aid programme has increased, the government has been paying more attention to its development impact. The article describes a decentralised model of aid in which Chinese provinces are responsible for aid to different sectors and in which implementers of projects have a great deal of autonomy as long as they can find ways to generate revenue, by having income-generation activities, for example. This pattern mimics the functioning of China's public sector, where agencies and departments are encouraged to identify revenue-generating activities to complement their government budget. The authors argue that China, as with most other providers of development aid, gives priority to global development and poverty reduction, but that the forms its assistance takes and the way projects are managed reflect China's development strategy and the specific nature of its government system.

Renwick tells the story of China's very longstanding engagement with its neighbours in 
Southeast Asia. He argues that China has tended to neglect its relations with these countries in recent years and has only recently begun to address the realities of a new competition for regional influence. This is illustrated with the case of Burma, with which China is actively seeking to build a strong relationship, but where it faces competition from other countries, which are providing substantial amounts of development assistance. Renwick argues that Burma could prove to be a litmus test for China's relations with Southeast Asia and the wider East Asia region.

Xue outlines the domestic institutional structures of China's development architecture, highlighting that the strengths of China's foreign assistance model, including its practical approach, pragmatic principles and reliance on high-level exchanges, may also be future weaknesses for it as an effective development actor. The article argues the need for reform of these aid institutions, and proposes a number of measures to ensure China's future capacity and effectiveness in foreign assistance.

The article by Schiere focuses on four so-called 'fragile states' in Africa. It describes the important role that Chinese investment is playing in these post-conflict countries. It argues that Chinese firms have been more willing to invest in these markets than companies based in the countries of the traditional donors. This is largely driven by their search for new markets and by competition from other Chinese firms. In many cases Chinese investment is potentially complementary to support provided by the traditional donors. However, as the article by $\mathrm{Gu}$ and Carty shows, this requires active coordination by the host government. Without this government leadership, there is a risk of fragmentation that could jeopardise post-conflict reconstruction. As China's investment increases in Africa, it has a growing stake in regional stability. This may explain its growing involvement in peacekeeping operations. Shiere argues that China is likely to face a growing challenge in reconciling its support for regional stability with its principle of respecting national sovereignty.

Gu and Carty argue that debates about China's engagement in Africa have been dominated by alternative visions of the future, with optimists seeing it as an opportunity for African countries to reduce their dependence on Western aid and on investments from Europe and North America, and pessimists predicting a new colonialism driven by China's need for access to raw materials and to markets for its manufactured goods. The view from China emphasises the principle of non-interference in domestic affairs and the priority of economic and social development over good governance. The authors contrast the experiences of the Democratic Republic of the Congo (DRC) and Rwanda to argue that the outcome of China's engagement is strongly influenced by the capacity and willingness of the local state to negotiate on their country's behalf. In the DRC, most investment has been in minerals and infrastructure. Chinese firms have negotiated substantial exemptions for customs and taxes and there have been a number of turnkey projects, with limited transfer of capacity to local organisations. On the other hand, in Rwanda, a relatively strong government has negotiated investments that have a longterm development potential. In both countries, the Chinese government has had limited influence on the behaviour of its firms.

The authors raise a number of paradoxes. Firstly, the Chinese go into Africa on a basis of equality and partnership and do not see how they can have the authority to impose standards of conduct which are not integral to a consensual relationship. Secondly - and this is especially clear in Chinese reflective literature - it is not clear to the Chinese how they should be expected to impose or even guide the development of standards which they do not have at home. Thirdly, China is itself engaging in a continuing process of economic reform, which means increasing privatisation. It is already the case that an increasing part of Chinese economic activity is private and outside the knowledge and control of central political authorities. Finally, China has, nonetheless, developed a doctrine of effective governance in Africa in which it stresses responsibility and accountability to the people. Governance is primarily about provision of basic services and social stability, a central Chinese objective at home and abroad.

Renwick tells the story of China's very longstanding engagement with its neighbours in Southeast Asia. He argues that China's relations with the region are at something of a crossroads as it begins to address the realities of a new competition for regional influence. This is 
illustrated with the case of Burma, with which China is actively seeking to build a strong relationship, but where it faces competition from other countries, which are providing substantial amounts of development assistance. Renwick argues that Burma could prove to be a litmus test for China's relations with Southeast Asia and the wider East Asia region.

Several articles focus on China's increasing role in discussions about the global architecture of aid and development. Abdenur adds another narrative from a Brazilian perspective, which presents China as a rising power actively seeking an important leadership role in the reform of the institutions of global development finance. The proliferation of these narratives is a testimony to the growing influence of the Chinese state and Chinese firms in the global economy and to the lack of a shared vision of the future or mutual understanding of the rules of engagement in international development. Abdenur explores China's engagement with the proposed BRICS Bank, arguing that China's motivation is largely political, since it allows China to demonstrate its commitment to multilateral action on development, build collaborative links with other rising powers and challenge the leadership of the major multilateral institutions. She suggests that negotiations about the directions the BRICS Bank will take will provide an important opportunity for the five countries to seek common ground.

$\mathrm{Xu}$ and Carey focus on the challenge of developing reporting and monitoring systems that take into account the quite different pattern of financial engagement by China in low- and middle-income countries. They argue that the close links between the state, large banks and private companies and the extensive use of government finance to support risk-taking mean that the current emphasis on documenting official aid flows does not reflect the new reality of development finance. They suggest that this is likely to precipitate major changes to existing reporting and monitoring systems.

The authors identify four 'primary narratives' of Western analysts to explain the nature and significance of overseas investment by Chinese state-owned enterprises: (i) China as a strong economic and political competitor; (ii) Chinese foreign investment as an instrument for achieving national security goals and strategies; (iii) Chinese companies as a promise of new opportunities for low-income countries; and (iv) Chinese companies and state as innovators in the global economy. These narratives reflect alternative visions of the future, views of the role and motives of the Chinese state, beliefs about the factors influencing Chinese firms and predictions about the way the changing global balance of power will be negotiated. $\mathrm{Xu}$ and Carey highlight how successful Chinese businesses have been able to transfer their business models to Africa, echoing the analysis of Li et al., which shows how China has been exporting its own development experiences to other developing countries.

This collection of articles illustrates the degree to which China's engagement in global development is a work in progress. They reveal the complex landscape of China's multi-level government and multi-sector engagements in international development, and their uncertain impacts. They show how a wide variety of actors in China, low-income countries, the other rising powers, the traditional donor countries, and multilateral agencies are still learning new ways of doing business in response. These actors need access to systematic information on this rapidly changing situation. The generation of knowledge for building mutual understanding will need to be done by researchers from the different countries involved. This will require new kinds of international research partnerships: the aim of this IDS Bulletin is to stimulate their creation. 